\title{
Recent Progress in Titanium Extraction and Recycling
}

\author{
OSAMU TAKEDA, TAKANARI OUCHI, and TORU H. OKABE
}

This paper presents a brief review of the history of titanium smelting and the current trends in related research and development. Presently, both electrolytic and metallothermic reduction processes utilizing various feed materials such as titanium oxide are widely studied. However, many challenges remain to be addressed before realizing the practical application of smelting processes utilizing oxide feed. To make titanium a "common metal", a new reduction process that is high speed, energy-efficient, low cost, and of low environmental impact is required. The current status of titanium recycling is likewise outlined, and the development of the recycling process is discussed. Low-grade titanium scraps heavily contaminated by oxygen and iron are currently used for producing additive alloys (ferro-titanium) in the steel industry. In the near future, if the demand for titanium metal increases dramatically, there could be an oversupply of low-grade titanium scraps in the market. Therefore, the development of anti-contamination and efficient removal processes for oxygen and iron is essential for the efficient utilization of titanium. The development of these technologies is vital for expanding the titanium industry through innovation in both titanium smelting and recycling technologies.

https://doi.org/10.1007/s11663-020-01898-6

(c) The Minerals, Metals \& Materials Society and ASM International 2020

\section{INTRODUCTION}

TITANIUM (Ti) is abundant in the earth's crust (0.7 mass pct as oxides). ${ }^{[1]}$ Metallic titanium shows excellent properties, such as the highest specific strength among structural metals [203-224 $\mathrm{kN} \mathrm{m} \mathrm{kg}^{-1}$ for Ti-6 mass pet Al-4 mass pet V (Ti 6-4) $\left.{ }^{[2]}\right]$ and high corrosion resistance even in aqueous solutions containing chlorine ions. ${ }^{[2]}$ However, titanium is a "rare metal." Its production volume (approximately $0.18 \mathrm{Mt}$ globally in $2015^{[3]}$ ) is significantly lower than those of iron $(\mathrm{Fe})$, aluminum $(\mathrm{Al})$, and copper $(\mathrm{Cu})$. The commercial production of titanium dates back only 70 years, which makes titanium a new metal compared with "common metals (e.g., $\mathrm{Fe}, \mathrm{Al}$, and $\mathrm{Cu})$ ". The first large-scale industrial production method (the Kroll process) was developed in the 1940s; however, the production technology is still in its early developmental stages. Hence, technological innovations are required to further scale up production. Moreover, if the production cost decreases, titanium could partially

OSAMU TAKEDA is with the Graduate School of Engineering, Tohoku University, 6-6-02 Aramaki-Aza-Aoba, Aoba-ku, Sendai 9808579, Japan. Contact e-mail: takeda@material.tohoku.ac.jp TAKANARI OUCHI and TORU H. OKABE are with the Institute of Industrial Science, The University of Tokyo, 4-6-1 Komaba, Meguro-ku, Tokyo 153-8505, Japan.

Manuscript submitted January 24, 2020.

Article published online July 7, 2020. replace stainless steel (the global production in 2018 was $\left.45.8 \mathrm{Mt}^{[3]}\right)$, leading to a drastic increase in its demand. Therefore, titanium is considered a "future material" whose production can be significantly scaled up by technical innovations, making it a "common metal". ${ }^{[2]}$

The history of titanium smelting and the current trends in related research and development are briefly reviewed in this paper. The current status of titanium recycling and its development processes are likewise discussed. The reviews ${ }^{[4-7]}$ cited in this paper will aid in understanding the detailed principles of the Kroll process and the previously proposed alternative processes. Other reviews ${ }^{[8-10]}$ are useful for understanding the detailed principles of recycling technologies.

\section{FROM DISCOVERY OF TITANIUM TO THE DEVELOPMENT OF INDUSTRIAL PRO- DUCTION PROCESSES: THERMOCHEMICAL- REDUCTION RESEARCH-ORIENTED ERA}

\section{A. Dawn of Titanium Industry}

In 1791, a British clergyman, R. W. Gregor, found an unknown oxide in iron sand sampled from a sandy coastal beach. ${ }^{[11]} \mathrm{He}$ named the oxide "menaccanite". Titanium production dates back to this discovery. In 1795, a German chemist, M. H. Klaproth, found a new 
metal oxide in a rutile ore in Hungary. He named the metallic element "Titanium," derived from the word "Titan" in Greek mythology. ${ }^{[1]}$ It was subsequently confirmed that titanium was identical to the element previously discovered by R. W. Gregor. At this stage, titanium oxide was separated from other oxides in iron sand or rutile ore; metallic titanium, however, could not be extracted by reducing titanium oxide. This was mainly due to the very strong chemical affinity between titanium and oxygen.

After the discovery of titanium by R. W. Gregor, numerous chemists attempted to extract metallic titanium, but with no success. The raw materials used in previous studies were oxide $\left(\mathrm{TiO}_{2}\right)$, potassium hexafluoro-titanate $\left(\mathrm{K}_{2} \mathrm{TiF}_{6}\right)$, titanium tetrachloride $\left(\mathrm{TiCl}_{4}\right)$, and other titanium compounds.

In 1825, J. J. Berzelius reduced $\mathrm{K}_{2} \mathrm{TiF}_{6}$ with potassium metal and obtained titanium containing a large amount of nitride. ${ }^{[1]}$ In 1887, L. F. Nilson and O. Petterson succeeded in producing 95 pct pure titanium metal. ${ }^{[12]}$ They chlorinated $\mathrm{TiO}_{2}$ with chlorine $\left(\mathrm{Cl}_{2}\right)$ gas under carbon monoxide (CO) gas to synthesize $\mathrm{TiCl}_{4}$ and then reduced the $\mathrm{TiCl}_{4}$ with sodium (Na) metal.

In 1910, M. A. Hunter succeeded in producing 99 pet pure titanium metal by reducing $\mathrm{TiCl}_{4}$ with sodium metal in a closed steel container. ${ }^{[13]}$ The reduction process that uses sodium metal as a reducing agent is currently termed as the "Hunter process" in honor of his achievement. The purity of the obtained titanium product excluding the gaseous elements was 99.9 pct. However, the titanium metal was brittle and not cold-workable because it was heavily contaminated with oxygen. After improving the impurity control methods during the reduction process, Hunter obtained cold-workable and high-purity titanium. The Hunter process was put to practical use in the 1950s and employed for large-scale production until 1993.

In 1923, Ruff and Brintzinger obtained 83 pct pure titanium metal by reducing $\mathrm{TiO}_{2}$ with calcium metal (Ca) ${ }^{[14]}$ W. Kroll, a Luxemburger metallurgist, obtained 98 pet pure titanium metal by using the same method. However, the titanium product was not hot-workable. ${ }^{[15]}$

In 1925, A. E. van Arkel and J. H. de Boer succeeded in producing high-purity titanium metal through a disproportionation reaction and the pyrolysis of crude titanium iodides $\left(\mathrm{TiI}_{x}\right) .{ }^{[16]}$ The oxygen concentration of the titanium product was very low, and the product was cold-workable. This method is termed the "iodide process" (or the van Arkel deBoer process). Despite its low productivity, the iodide process was employed to produce high-purity titanium for the semiconductor industry.

In 1940, W. Kroll developed a titanium production process by reducing $\mathrm{TiCl}_{4}$ with magnesium $(\mathrm{Mg})$ metal; ${ }^{[17]}$ the obtained titanium product was called "titanium sponge." The US Bureau of Mines further developed this process for large-scale production. Titanium metal was first introduced to the market in 1948. ${ }^{[18]}$ In 1950, titanium sponge was produced using the same method on a laboratory scale in Japan. ${ }^{[19]}$ The reduction process of $\mathrm{TiCl}_{4}$ with magnesium metal is termed as the "Kroll process" and is the most commonly employed titanium smelting process.

\section{B. Kroll Process}

The Kroll process involves four sub-processes: (1) the chlorination process, where titanium oxide feed is chlorinated in the presence of carbon to produce $\mathrm{TiCl}_{4}$; (2) the reduction and separation process, where $\mathrm{TiCl}_{4}$ is reduced with magnesium metal, from which titanium sponge is recovered; (3) the crushing and melting process, where crushed titanium sponge is melted in a vacuum arc or an electron-beam furnace; and (4) the electrolysis process, where magnesium chloride $\left(\mathrm{MgCl}_{2}\right)$, separated in the reduction and separation processes, is electrolyzed into $\mathrm{Cl}_{2}$ gas and magnesium metal.

Titanium occurs as an oxide in nature. Rutile ore with a $\mathrm{TiO}_{2}$ grade of approximately 95 pct, upgraded ilmenite (UGI), or upgraded titanium slag (UGS) is utilized as a feed material for titanium metal production. UGI (or UGS) is a chemically enriched ilmenite ore whose original $\mathrm{TiO}_{2}$ grade is approximately 50 pct. Rutile or UGI (or UGS) powder is placed into a fluidized bed furnace, where the powder reacts with $\mathrm{Cl}_{2}$ gas in the presence of coke at approximately $1300 \mathrm{~K}$. Crude $\mathrm{TiCl}_{4}$ is obtained by the following carbochlorination reaction:

$$
\mathrm{TiO}_{2}(s)+2 \mathrm{Cl}_{2}(g)+\mathrm{C}(s)=\mathrm{TiCl}_{4}(g)+\mathrm{CO}_{2}(g)
$$

Impurities such as $\mathrm{FeCl}_{x}$ and $\mathrm{AlCl}_{3}$, which have higher boiling points than that of $\mathrm{TiCl}_{4}(409 \mathrm{~K})$, are removed by condensation in this process. Impurities such as $\mathrm{VOCl}_{3}, \mathrm{SnCl}_{4}$, and $\mathrm{SiCl}_{4}$, which have boiling points similar to that of $\mathrm{TiCl}_{4}$, remain in the $\mathrm{TiCl}_{4}$ intermediate. $\mathrm{VOCl}_{3}$ is reduced by a reducing agent such as hydrogen sulfide $\left(\mathrm{H}_{2} \mathrm{~S}\right)$ for conversion into vanadium tetrachloride $\left(\mathrm{VCl}_{4}\right)$, which has a higher boiling point than that of $\mathrm{VOCl}_{3}$. $\mathrm{SnCl}_{4}$ and $\mathrm{SiCl}_{4}$ are removed by a multistep distillation process. High-purity (>99.98 pct) $\mathrm{TiCl}_{4}$ is finally obtained after the distillation process.

A schematic illustration of a steel reduction container used for titanium metal production from the $\mathrm{TiCl}_{4}$ feed is shown in Figure 1. The container containing magnesium metal is kept under argon gas at $1100 \mathrm{~K}$, and high-purity $\mathrm{TiCl}_{4}$ is fed into the container. The reduction of $\mathrm{TiCl}_{4}$ is described by the following equation:

$$
\mathrm{TiCl}_{4}(l, g)+2 \mathrm{Mg}(l)=\mathrm{Ti}(s)+2 \mathrm{MgCl}_{2}(l)
$$

Because this reaction is highly exothermic, the container is strongly heated during the reduction process. A molten $\mathrm{Ti}-\mathrm{Fe}$ alloy forms over a eutectic point in the Ti-Fe system $\left(1358 \mathrm{~K}, 1085{ }^{\circ} \mathrm{C}\right)$, which results in the rapid alloying of titanium and steel, causing serious damage to the container. Therefore, the reduction temperature is rigorously controlled below $1358 \mathrm{~K}$ by regulating the $\mathrm{TiCl}_{4}$ feed rate and cooling the container.

Through the reduction process, titanium metal grows as a porous deposit, termed as "titanium sponge," on the inner wall of the container. Titanium sponge contains $\mathrm{MgCl}_{2}$ and unreacted magnesium metal inside 


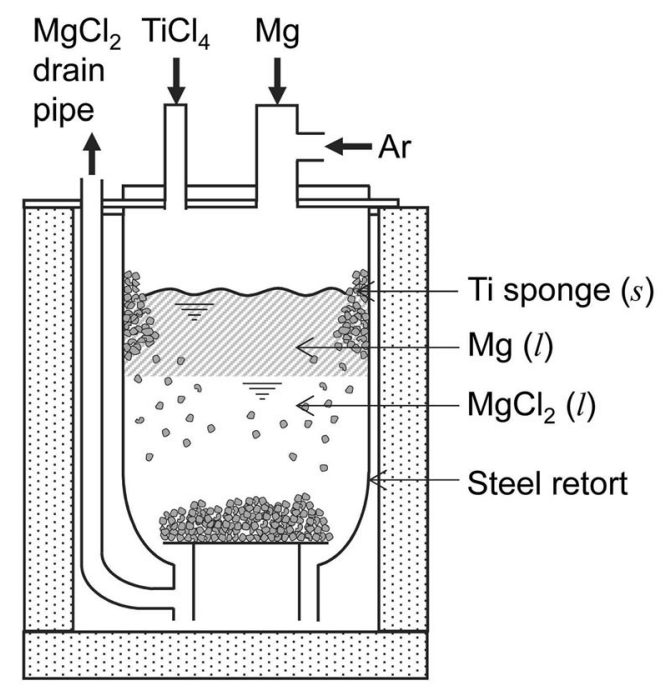

(a)

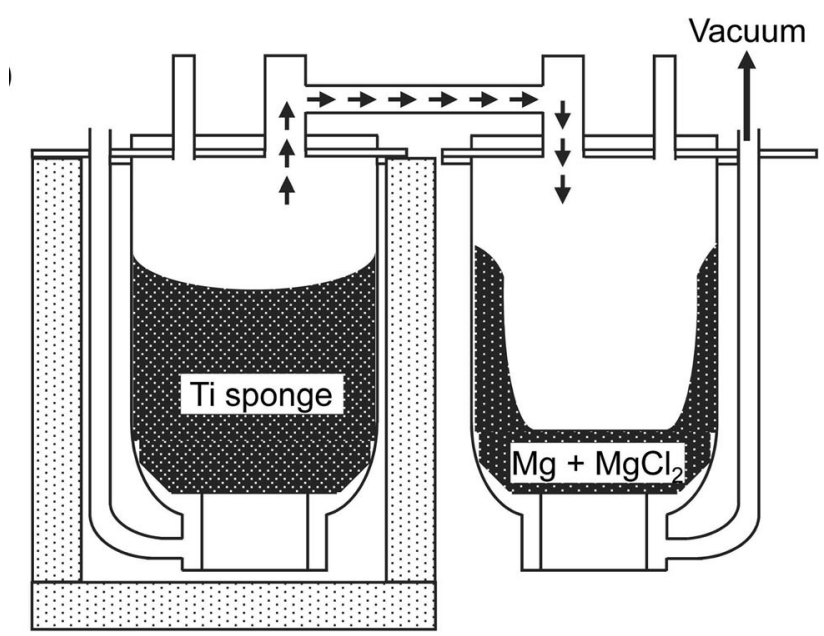

(b)

Fig. 1-Schematic illustration of the reaction system in the Kroll process. (a) Magnesiothermic reduction of $\mathrm{TiCl}_{4}$. (b) Removal of $\mathrm{Mg}$ and $\mathrm{MgCl}_{2}$ from titanium sponge by vacuum distillation.

the pores. $\mathrm{MgCl}_{2}$ periodically tapped out from the reduction container during the reduction process is transferred to the electrolysis process.

After the completion of the reduction reaction, $\mathrm{MgCl}_{2}$ and the excess magnesium metal left in the titanium sponge are removed through vacuum distillation (0.1-1 $\mathrm{Pa}$ ) at $1273 \mathrm{~K}$. The vacuum separation of $\mathrm{MgCl}_{2}$ and magnesium metal from the titanium sponge in a $10 \mathrm{t}$ batch requires approximately $90 \mathrm{~h}$. The evaporation of magnesium metal and $\mathrm{MgCl}_{2}$ is endothermic, thus requiring a heat supply to assist the evaporation in vacuum. Supplying heat deep inside the titanium sponge is technically difficult, particularly for a large-scale batch; therefore, vacuum evaporation takes a long time.

The vacuum separation process is followed by a prolonged cooling process. The titanium sponge recovered from the reduction container is mechanically separated using a die cutter and pulverized into small pieces. After quality inspection, the titanium sponge is transferred to the melting process for titanium ingot production. Some parts of this titanium sponge, particularly the deposit near the inner wall of the reduction container, are heavily contaminated with iron. The most important feature of the Kroll process is the reliable production of titanium metal with a low oxygen concentration of approximately 500 mass-ppm.

Because titanium metal adheres to various locations in the container during the reduction process, its continuous recovery is difficult. Therefore, a batch process involving container preparation, reduction, distillation, cooling, and titanium recovery is applied. Recently, large-scale facilities capable of producing $13 \mathrm{t}$ of titanium per container have been constructed. However, the production speed of titanium is still low, and the duration of one cycle lasts more than 10 days, i.e., the production speed per container is approximately $1 \mathrm{t}$ of titanium per day. ${ }^{[20,21]}$

\section{ELECTROLYSIS RESEARCH-ORIENTED ERA: FROM 1950S TO 1970S}

In 1904, Borchers and Hupperts reported titanium production by electrolysis, ${ }^{[22]}$ where $\mathrm{TiO}_{2}$ was electrolyzed in molten alkaline-earth halide. However, the characteristics of the titanium obtained by this process were unclear. The product was possibly heavily contaminated by oxygen and carbon. After the development of the industrial production of titanium by the Kroll process, many researchers have intensively studied the electrochemical reduction of titanium as a post-Kroll titanium production process. ${ }^{[23]}$

Di-, tri-, and tetravalent cations are known as stable titanium ions. Tri- and tetravalent cations are stable even in an aqueous solution. However, the standard redox potentials of $\mathrm{Ti} / \mathrm{Ti}^{2+}$ and $\mathrm{Ti}^{2+} / \mathrm{Ti}^{3+}$ are significantly less noble and are outside the electrochemical window of water. Therefore, titanium metal production in an aqueous solution is thermodynamically not feasible. To date, an organic solvent that can be used as a non-aqueous solvent suitable for the reduction of titanium ions has not been found owing to the very strong chemical affinity of titanium to oxygen and nitrogen. The electrowinning of titanium metal in molten salt has been studied intensively.

In the 1960 s, some industrialization studies on electrolytic methods led to the construction of pilot plants. The methods were based on the electrolysis of titanium chloride in molten chloride. National Lead Co. developed a basket cathode method, ${ }^{[24]}$ where $\mathrm{TiCl}_{4}$ was introduced into a basket cathode immersed in molten salt, and the titanium component was dissolved into an electrolyte by reacting $\mathrm{TiCl}_{4}$ with the titanium metal product or $\mathrm{Ti}^{2+}$ ions in the electrolyte. The titanium deposit was obtained by reducing the $\mathrm{Ti}^{2+}$ ions. New Jersey Zinc Co. employed various diaphragms that separated the anode and cathode compartments. ${ }^{[25]}$ In the buildup stage of the electrolytic bath, $\mathrm{TiCl}_{4}$ and titanium metal were introduced into the bath inside the cathode compartment to form the $\mathrm{Ti}^{2+}$ ions. $\mathrm{TiCl}_{4}$ was then introduced into the bath to be dissolved to form 
lower-valence ions, and $\mathrm{Ti}^{2+}$ was finally reduced on the cathode to recover titanium metal. The US Bureau of Mines preliminarily produced $\mathrm{Ti}^{2+}$ by the electrochemical reduction of $\mathrm{TiCl}_{4}{ }^{[26]}$ The titanium deposit was obtained by reducing the $\mathrm{Ti}^{2+}$ ion on the cathode. Industrial production using the abovementioned electrolytic methods was expected, but the industrialization did not succeed. Recently, Hsueh et al. developed a diaphragm system that eliminates extraneous bipolar reactions in the cell although its details are unclear. ${ }^{[27]}$ They claimed that the stack of thin diaphragms enables stable cell voltage and efficient electrowinning of titanium.

Oki and Inoue studied the direct reduction of $\mathrm{TiO}_{2}$ in a molten salt by electrolysis. They placed $\mathrm{TiO}_{2}$ powder in the vicinity of a cathode immersed in molten $\mathrm{CaCl}_{2}$ and subsequently electrolyzed it to obtain titanium metal. ${ }^{[28]}$ This method can be considered as the prototype of the FFC (Fray-Farthing-Chen) ${ }^{[29]}$ and OS (Ono-Suzuki) processes, ${ }^{[30]}$ which are discussed later. This was a pioneering work; however, the atmosphere control capabilities of the electrolytic reduction method were inadequate. Therefore, the purity of the obtained titanium was low, and their work was not evaluated.

Numerous other electrolytic methods were investigated; however, none of them reached industrialization. The major reasons were (1) low current efficiency owing to the formation of multi-valent titanium ions, (2) difficult separation between the titanium deposit and the electrolytic bath, (3) low productivity due to a slower reaction rate than that obtained in metallothermic reduction, and (4) low space utilization efficiency in the electrolytic cell.

\section{MULTIPLE METHOD-ORIENTED ERA: FROM 1980S TO PRESENT}

\section{A. Processes Utilizing Electrolytic and Metallothermic Reduction}

To develop a next-generation process for replacing the low-productivity Kroll process, researchers intensively studied electrolytic methods in the 1970s. The industrialization of these methods, however, did not succeed. Since 1980, processes utilizing both electrolytic and metallothermic reduction have been widely studied. ${ }^{[4]}$ Raw materials were diversified to include oxide, chloride, and fluoride, among others (Figure 2). Reducing agents were likewise diversified to include calcium, magnesium etc., with many combinations.

Among these combinations, the development of reduction processes of titanium oxide using calcium metal as a reducing agent advanced in particular.

Ono and Miyazaki conducted the pioneering research on calcium deoxidation. ${ }^{[31]}$

$$
\underline{\mathrm{O}}(\text { in } \mathrm{Ti}(s))+\mathrm{Ca}(l, g)=\mathrm{CaO}(s)
$$

Okabe et al. developed the Ca-halide flux deoxidation process, ${ }^{[32-35]}$ where the activity of $\mathrm{CaO}$ was decreased by dissolving $\mathrm{CaO}$ into molten $\mathrm{CaCl}_{2}$. This enabled a high deoxidation capability.

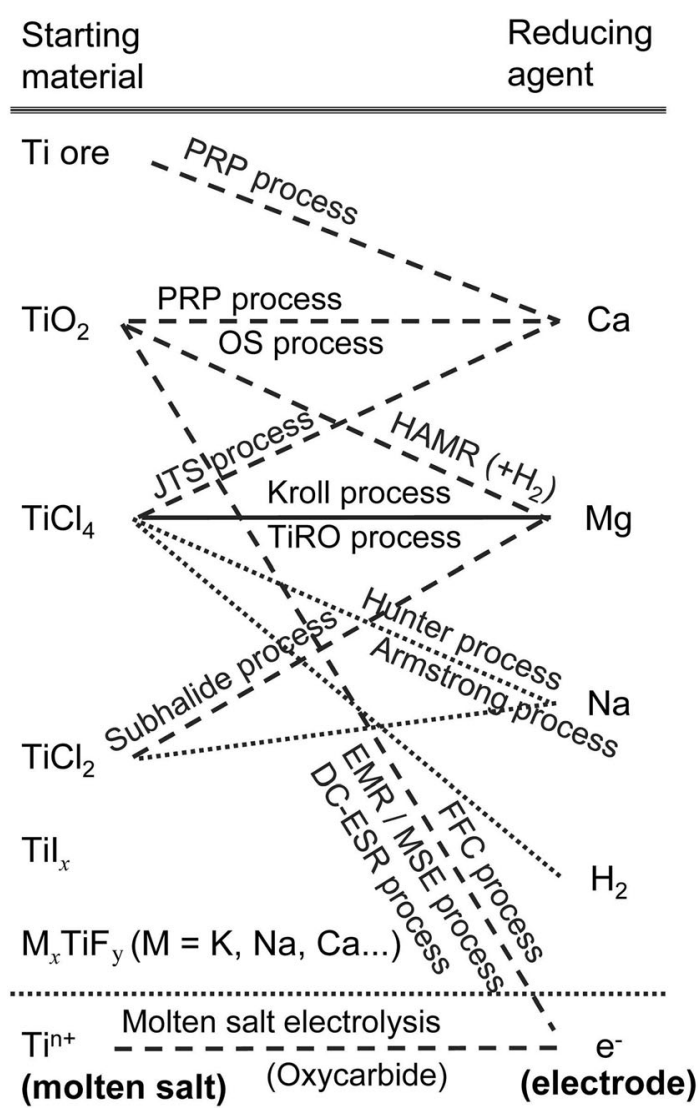

Fig. 2-Relationship between starting materials and reducing agents of several reduction processes.

$$
\underline{\mathrm{O}}(\text { in } \mathrm{Ti}(s))+\mathrm{Ca}(l)=\underline{\mathrm{CaO}}\left(\text { in } \mathrm{CaCl}_{2}(l)\right)
$$

Furthermore, Okabe et al. developed an electrochemical deoxidation process to produce ultralow-oxygen titanium. ${ }^{[36]}$ In this method, the activity of $\mathrm{CaO}$ in molten $\mathrm{CaCl}_{2}$ was kept very low by removing the $\mathrm{O}^{2-}$ ions on the anode (Eq. [6]), which enabled ultra-high deoxidation $(<10$ mass-ppm).

$$
\underline{\mathrm{O}}(\text { in } \mathrm{Ti}(s))+\mathrm{Ca}(l)=\underline{\mathrm{CaO}}\left(\text { in } \mathrm{CaCl}_{2}(l)\right)
$$

$$
\begin{aligned}
\text { Anode } & : 2 \mathrm{O}^{2-}\left(\text { in } \mathrm{CaCl}_{2}(l)\right)+\mathrm{C}(s) \\
& =\mathrm{CO}_{2}(g)+4 e^{-}
\end{aligned}
$$

$$
\text { Cathode : } 2 \mathrm{Ca}^{2+}\left(\text { in } \mathrm{CaCl}_{2}(l)\right)+4 e^{-}=2 \mathrm{Ca}(l)
$$

Following the development of electrochemical deoxidation, Fray et al. investigated the removal of oxide scale from titanium scrap and developed a direct production process of titanium metal from oxide raw materials (the FFC process). ${ }^{[2,37,38]}$ They proposed the following deoxidation principle:

$$
\underline{\mathrm{O}}(\text { in } \mathrm{Ti}(s))+2 e^{-}=\mathrm{O}^{2-}\left(\text { in } \mathrm{CaCl}_{2}(l)\right)
$$


This work attracted the attention of numerous researchers, and similar studies have been intensively conducted worldwide (Figure 3).

Ono and Suzuki likewise developed a direct production process of titanium metal from $\mathrm{TiO}_{2}$ (the $\mathrm{OS}$ process). ${ }^{[30]}$ They proposed the following calciothermic reduction of $\mathrm{TiO}_{2}$ in molten salt:

$$
\begin{aligned}
& \text { Anode : } 2 \mathrm{O}^{2-}\left(\text { in } \mathrm{CaCl}_{2}(l)\right)+\mathrm{C}(s) \\
& =\mathrm{CO}_{2}(g)+4 e^{-}
\end{aligned}
$$

$$
\begin{aligned}
\text { Cathode }: & 2 \mathrm{Ca}^{2+}\left(\text { in } \mathrm{CaCl}_{2}(l)\right)+4 e^{-} \\
& =2 \mathrm{Ca}\left(\text { in } \mathrm{CaCl}_{2}(l)\right)
\end{aligned}
$$

$$
\begin{aligned}
\mathrm{TiO}_{2} & (s)+2 \underline{\mathrm{Ca}}\left(\text { in } \mathrm{CaCl}_{2}(l)\right) \\
= & \mathrm{Ti}(s)+2 \mathrm{O}^{2-}\left(\text { in } \mathrm{CaCl}_{2}(l)\right) \\
& +2 \mathrm{Ca}^{2+}\left(\operatorname{in~} \mathrm{CaCl}_{2}(l)\right)
\end{aligned}
$$

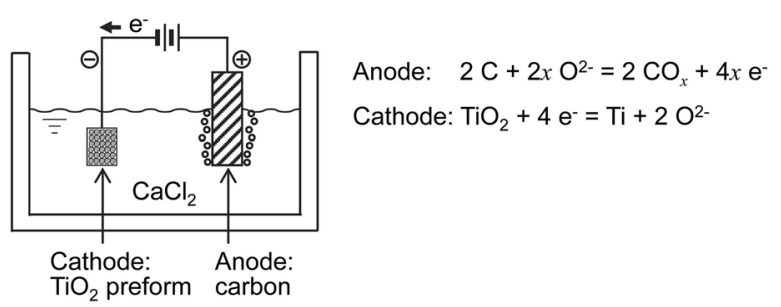

(a) FFC process (Fray et al.)

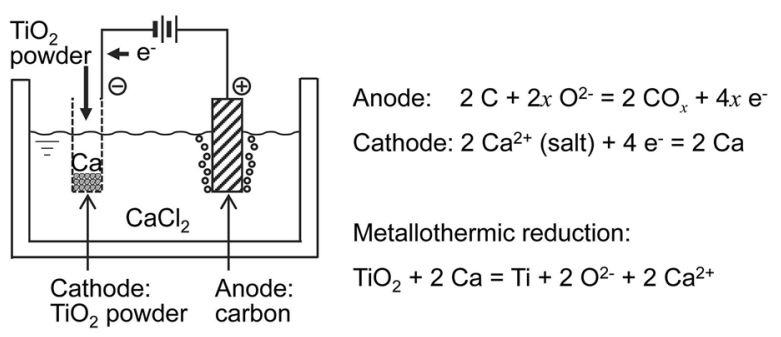

(b) OS process (Ono and Suzuki)

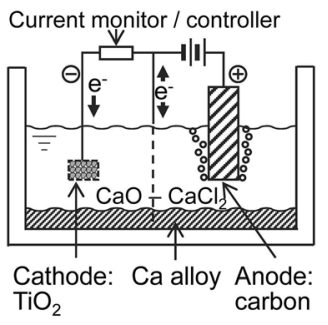

MSE (Molten Salt Electrolysis)

Anode: $2 \mathrm{C}+2 x \mathrm{O}^{2-}=2 \mathrm{CO}_{x}+4 x \mathrm{e}^{-}$

Cathode: $2 \mathrm{Ca}^{2+}$ (salt) $+4 \mathrm{e}^{-}=2 \mathrm{Ca}$ (alloy)

EMR (Electronically Mediated Reaction)

Anode: $2 \mathrm{Ca}$ (alloy) $=2 \mathrm{Ca}^{2+}+4 \mathrm{e}^{-}$

Cathode: $\mathrm{TiO}_{2}+4 \mathrm{e}^{-}=\mathrm{Ti}+2 \mathrm{O}^{2-}$

(c) EMR / MSE process (Okabe et al.)

Fig. 3-Comparison of various titanium reduction processes utilizing titanium oxide as raw material.
Calcium metal electrolyzed on the cathode dissolves into molten $\mathrm{CaCl}_{2}$ to form a strongly reducing molten salt. $\mathrm{TiO}_{2}$ powder immersed into the molten salt is reduced to titanium metal powder. The $\mathrm{O}^{2-}$ ion in the molten salt is removed as $\mathrm{CO}_{2}$ on the anode.

A potential diagram for the Ti-Cl-O system is shown in Figure $4{ }^{[39]}$ to illustrate the difference between the reduction processes of the chloride and oxide feeds. The horizontal and vertical axes show the partial pressures of chlorine and oxygen, respectively.

The reduction path in direct production processes for titanium metal from oxide feed, such as the FFC and OS processes, is shown in (1) (points a to b) of Figure 4, whereas the reduction path in an indirect production process from chloride feed, such as in the Kroll process, is shown in (2) (points c to d, and e). During the actual reduction process from oxide feed, a complex oxide or oxycarbide might form. In the direct production process, low-cost titanium production is expected by omitting the chloride synthesis step (points c to d) and by making the reduction process continuous. The direct reduction of titanium oxide seems reasonable as a reduction process; however, an inexpensive method for the production of high-purity titanium oxide by removing iron, aluminum, silicon, etc., from titanium ores has not been developed to date. At this stage, the purity of $\mathrm{TiO}_{2}$ obtained by upgrading is 96 pct at most, and a more advanced process, like the Bayer process in aluminum smelting (purity of $\mathrm{Al}_{2} \mathrm{O}_{3}$ achieved is $99.5 \mathrm{pct}$ ), is required. Calcium metal is the only practical reductant for the direct reduction of oxide raw materials $\left(\mathrm{TiO}_{x}\right)$ to titanium metals with low oxygen-concentration. However, the production of calcium metal is technically difficult and costly today. The development of an electrolytic cell with long-term high stability is

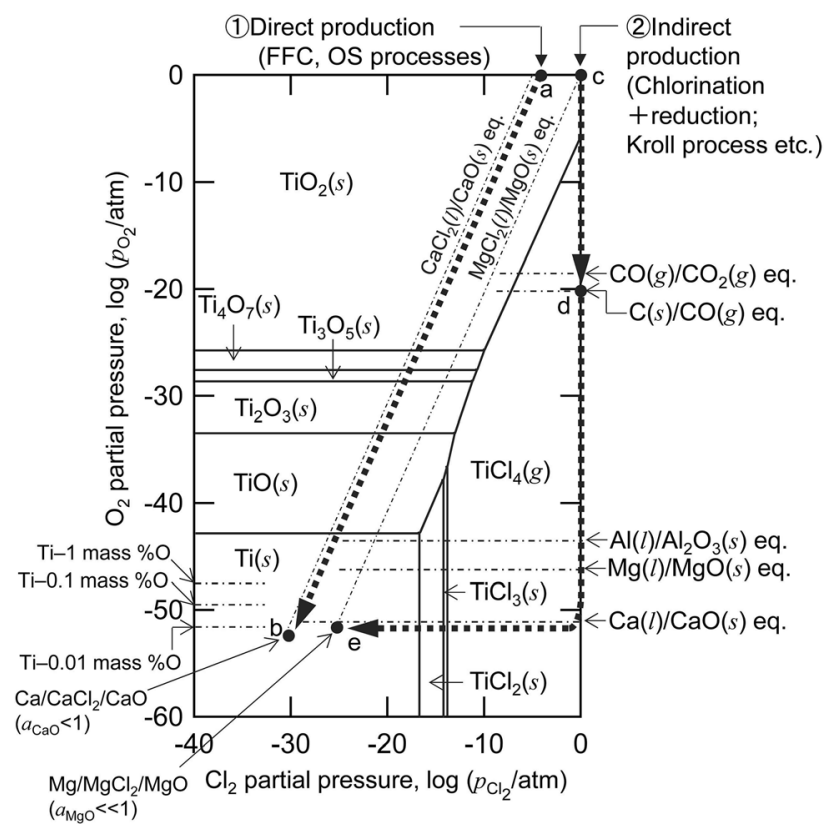

Fig. 4 - Chemical potential diagram for Ti-Cl-O system at 1073 $\mathrm{K}^{\left[{ }^{[9]}\right.}$ Reaction pathways for various reduction processes are indicated. 
difficult as calcium easily reacts with carbon and oxygen. There are numerous challenges that have to be addressed before realizing the practical application of titanium smelting utilizing oxide feed.

When chloride feed is employed for titanium reduction, magnesium, sodium, and calcium have proved effective as reducing agents in the production of high-purity titanium. The reduction of $\mathrm{TiCl}_{4}$ with calcium and sodium is suitable for constructing a continuous reduction process because titanium powder product is obtained. Calciothermic and sodiothermic reductions of $\mathrm{TiCl}_{4}$ are employed in the Japan Titanium Society (JTS) process ${ }^{[40]}$ and the Armstrong process, ${ }^{[41]}$ respectively. However, an efficient cooling technology for the reactor and efficient utilization of the reaction heat is required as the heat generated in these reduction processes is greater than that in the magnesiothermic reduction of $\mathrm{TiCl}_{4}$. Furthermore, the removal of byproducts such as $\mathrm{CaCl}_{2}$ and $\mathrm{NaCl}$ by evaporation is difficult because their vapor pressures are low. Instead, leaching or remelting separation at temperatures higher than the melting point of titanium metal should be conducted.

\section{B. Latest Trends in Research and Development}

A UK-based venture company, Metalysis, developed a pilot-scale electrolytic cell for the industrialization of the FFC process, producing low-cost titanium powder. ${ }^{[42]}$ It was reported ${ }^{[43]}$ that Cristal Metals (previously ITP Co.) in USA constructed a production plant with a 2000-ton capacity in Ottawa, Illinois, for the production of titanium powder via the Armstrong process. The Armstrong process is based on the sodiothermic reduction of $\mathrm{TiCl}_{4}$ in the gas phase.

$$
\mathrm{TiCl}_{4}(g)+4 \mathrm{Na}(l)=\mathrm{Ti}(s)+4 \mathrm{NaCl}(l)
$$

Okabe et al. developed a preform reduction process (PRP), wherein a preform formed from titanium oxide feed is reduced by calcium vapor (Figure 5). ${ }^{[44-47]}$

$$
\mathrm{TiO}_{2}(s)+2 \mathrm{Ca}(g)=\mathrm{Ti}(s)+2 \mathrm{CaO}(s)
$$

The PRP has the advantage of scalability because the preform is suitable for homogeneous heat treatment. Furthermore, the PRP has good anti-contamination ability because the preform is a self-supporting structure and its contact area with the reactor material is very small.

Among electrolytic methods, a smelting process using titanium oxycarbide (TiCO) (Figure 6) has been actively studied. Titanium oxycarbide, obtained through the carbothermic reduction of $\mathrm{TiO}_{2}$, is used as the anode, and titanium metal is produced through electrorefining in a molten salt.

$$
\begin{gathered}
\begin{aligned}
\text { Anode }: & \operatorname{TiCO}(s)+2 e^{-} \\
& =\mathrm{Ti}^{2+}(l \text { in salt })+\mathrm{CO}(g)
\end{aligned} \\
\text { Cathode }: \mathrm{Ti}^{2+}(l \text { in salt })+2 e^{-}=\mathrm{Ti}(s)
\end{gathered}
$$

\section{Feed preform $\left(\mathrm{TiO}_{2}\right.$ feed + flux $)$}

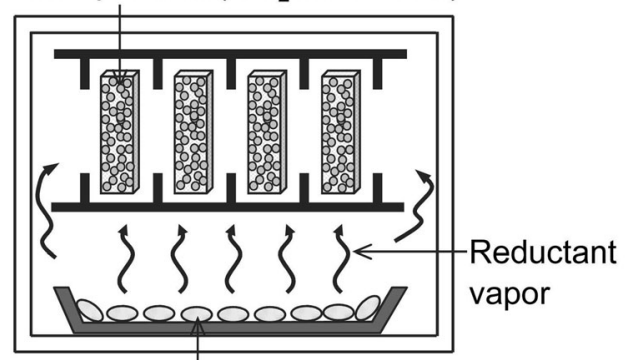

Reductant $(\mathrm{R}=\mathrm{Ca}$, or Ca-X alloy)

$$
\begin{aligned}
& \mathrm{TiO}_{2}(s)+2 \mathrm{Ca}(g)=\mathrm{Ti}(s)+2 \mathrm{CaO}(s) \\
& \text { Fe-removed Ti-Ore }(s)+\mathrm{Ca}(\mathrm{g})=\mathrm{Ti}(s)+\mathrm{CaO}(s)
\end{aligned}
$$

Fig. 5-Schematic illustration of reaction system in the preform reduction process (PRP). ${ }^{[4-47]}$

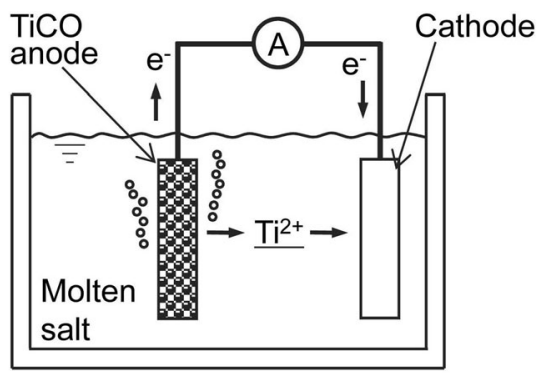

Anode: $\operatorname{TiCO}(s)+2 \mathrm{e}^{-}=\mathrm{Ti}^{2+}(l$ in salt $)+\mathrm{CO}(g)$ Cathode: $\mathrm{Ti}^{2+}(l$ in salt $)+2 \mathrm{e}^{-}=\mathrm{Ti}(s)$

Fig. 6-Schematic illustration of the reaction system in molten salt electrolytic refining process using oxycarbide anode. ${ }^{[48-53]}$

In 1952, Wainer reported the development of oxycarbide electrolysis. ${ }^{[4]}$ In 1960s, Takeuchi and Watanabe $^{[49]}$ and Hashimoto ${ }^{[50]}$ in Japan conducted systematic studies on this electrolysis, and in 2000s and later, Jiao and Zhu, ${ }^{[51]}$ MER Co., ${ }^{[52]}$ and White Mountain Titanium Co. ${ }^{[53]}$ developed the electrolysis further.

In the Kroll process, titanium metal forms as a solid, hindering the construction of a continuous titanium production process. Therefore, the recovery of titanium products in liquid form has been attempted. Halomet $^{[54]}$ proposed the magnesiothermic reduction of $\mathrm{TiCl}_{4}$ at high pressure $(0.5$ to $1 \mathrm{MPa})$ and high temperature (above $1973 \mathrm{~K}$ ) to recover molten titanium metal. However, the practical development did not succeed owing to the lack of suitable container materials and to the strict temperature control requirements. Recently, Ginatta developed an electrowinning process for molten titanium metal although its details are unclear. ${ }^{[55-57]}$ The electrolysis was conducted at a temperature of over $1973 \mathrm{~K}$ by feeding $\mathrm{TiCl}_{4}$ into a molten fluoride electrolyte. Ginatta claimed that "solid electrolytic skin" maintained by external cooling can hold molten salt and molten titanium at high temperatures. However, it seems that very rigorous and sophisticated thermal management inside the electrolytic cell is required. 
Hard and Prieto ${ }^{[58]}$ proposed an aluminothermic reduction of $\mathrm{Na}_{2} \mathrm{TiF}_{6}$ in the presence of molten zinc metal $(\mathrm{Zn})$ to recover the molten $\mathrm{Zn}$-Ti alloy. Titanium sponge was recovered by removing zinc from the $\mathrm{Zn}-\mathrm{Ti}$ alloy through vacuum distillation. Kimura et $a ._{.}{ }^{[59]}$ proposed the magnesiothermic reduction of $\mathrm{TiCl}_{4}$ in the presence of molten zinc, lead $(\mathrm{Pb})$, or copper to form a $\mathrm{Zn}-\mathrm{Ti}$ alloy, $\mathrm{Pb}-\mathrm{Ti}$ alloy, or $\mathrm{Cu}-\mathrm{Ti}$ alloy for the purpose of developing a continuous reduction process. Deura et al. ${ }^{[60]}$ mixed $\mathrm{TiO}_{2}$ and nickel $(\mathrm{Ni})$ powders to fabricate a composite cathode. The $\mathrm{TiO}_{2}$ inside the cathode was reduced by calcium metal electrolyzed in molten $\mathrm{CaCl}_{2}$ to form a molten Ti-Ni alloy.

Recently, Kado et al. ${ }^{[61]}$ proposed the magnesiothermic reduction of $\mathrm{TiCl}_{4}$ with molten bismuth (Bi) as a collector metal for titanium, where the molten $\mathrm{Bi}-\mathrm{Ti}$ alloy is recovered as the product (Figure 7).

$$
\operatorname{TiCl}_{4}(l, g)+2 \mathrm{Mg}(l \text { in } \mathrm{Bi})=\underline{\mathrm{Ti}}(l \text { in } \mathrm{Bi})+2 \mathrm{MgCl}_{2}(l)
$$

Subsequently, titanium metal is recovered by removing bismuth from the Bi-Ti alloy by evaporation.

When molten titanium alloy is utilized, the titanium product can be continuously recovered from the reduction vessel, and the construction of a continuous reduction process is anticipated.

Fang et al. developed the hydrogen-assisted magnesiothermic reduction (HAMR) process (Figure 8). ${ }^{[62]}$ Thermodynamically, the magnesium deoxidation capability for the oxide system is low. However, the oxygen in titanium is destabilized by hydride formation and removed, according to the following equation:

$$
\underline{\mathrm{O}}(\text { in } \mathrm{Ti}-\mathrm{H}(s))+\mathrm{Mg}(l, g)=\mathrm{MgO}(s)
$$

The use of magnesium metal as the reducing and deoxidation agent is advantageous because of its low cost compared with that of calcium metal. Furthermore, magnesium has good recyclability.

Takeda and Okabe ${ }^{[63-65]}$ developed the magnesiothermic reduction of titanium subhalide $\left(\right.$ e.g., $\left.\mathrm{TiCl}_{2}\right)$, which they called the subhalide reduction process (Figure 9), with the aim to establish a continuous and high-speed reduction process that is desired in the Kroll process.

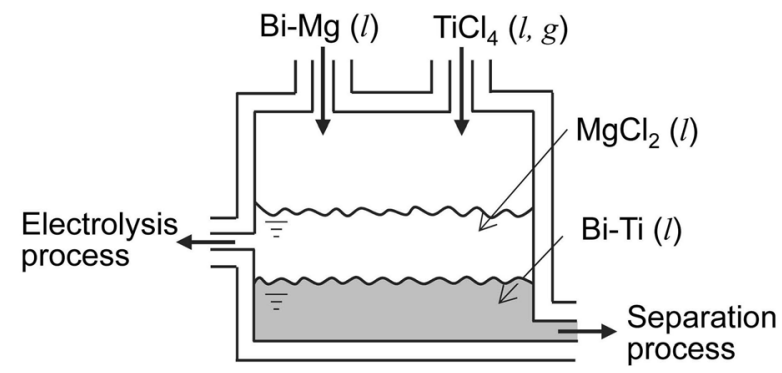

$\mathrm{TiCl}_{4}(l, g)+2 \underline{\mathrm{Mg}}(l$ in Bi$)=\underline{\mathrm{Ti}}(l$ in $\mathrm{Bi})+2 \mathrm{MgCl}_{2}(l)$

Fig. 7-Schematic illustration of the reaction system in the magnesiothermic reduction of $\mathrm{TiCl}_{4}$ using molten $\mathrm{Bi}$ as the collector metal. $^{[61]}$

$$
\mathrm{TiCl}_{2}(s)+\operatorname{Mg}(l)=\operatorname{Ti}(s)+\operatorname{MgCl}_{2}(l)
$$

The advantages of this reduction process are as follows. (1) Faster reduction is possible because the reaction heat is relatively low, and the reaction proceeds three-dimensionally in a condensed phase. (2) Iron contamination is prevented using a titanium reactor. In the Kroll process, a titanium reactor cannot be used because $\mathrm{TiCl}_{4}$ reacts with titanium to form $\mathrm{TiCl}_{2}$. On the other hand, $\mathrm{TiCl}_{2}$ equilibrates with titanium metal, and a titanium reactor can be used in the subhalide reduction process. (3) Semi-continuous reduction with a small lot size is possible. Lastly, (4) effective utilization of titanium scraps as a raw material is possible for establishing an environmentally sound process.

Extensive research has been ongoing to develop a next-generation titanium production method aimed at overcoming the low productivity of the Kroll process. However, no practical method replacing the Kroll process has been proposed to date. Therefore, a new reduction process has to be established to make titanium a "common metal" (Figure 10). This process should be high speed, energy efficient, low cost, and have a low environmental impact. A breakthrough in elemental technologies is anticipated.

\section{REAL PICTURE OF TITANIUM RECYCLING}

Titanium recycling is generally considered to be the recycling of post-consumer titanium products. However, at present, such recycling is not a priority on the industrial scale as titanium is mainly used for long-life products, such as structural materials for aircraft frames and heat exchangers in power plants. Although the demand for these products is currently increasing, their lifetime is quite long, at over 10 years. Hence, the current volume of scrap generation is limited, and a substantial volume cannot be collected yet from the consumer market.

The nominal recycling rate, which is the ratio of the statistical recycling volume of post-consumer titanium products to the production volume of titanium sponge, is quite low (less than $1 \mathrm{pct}$ ). ${ }^{[66]}$ This value is miniscule

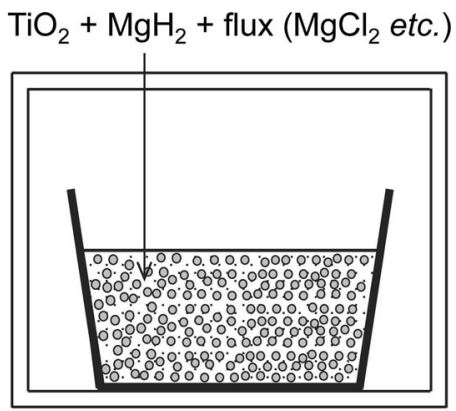

$\mathrm{TiO}_{2}(s)+2 \mathrm{MgH}_{2}(s)=\mathrm{TiH}_{2}(s)+2 \mathrm{MgO}(s)+\mathrm{H}_{2}(g)$

Fig. 8-Schematic illustration of the reaction system in the hydrogen-assisted magnesiothermic reduction (HAMR) process. ${ }^{[62]}$ 


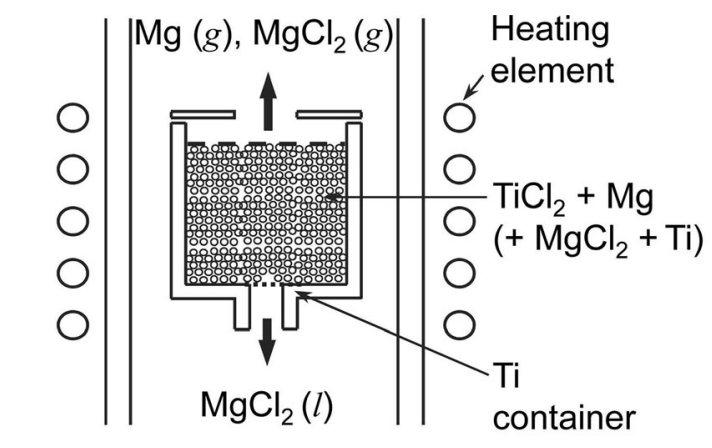

$$
\operatorname{TiCl}_{2}(s)+\mathrm{Mg}(l) \rightarrow \mathrm{Ti}(s)+\mathrm{MgCl}_{2}(l)
$$

Fig. 9-Schematic illustration of the reaction system in subhalide reduction process. ${ }^{[63-65]}$

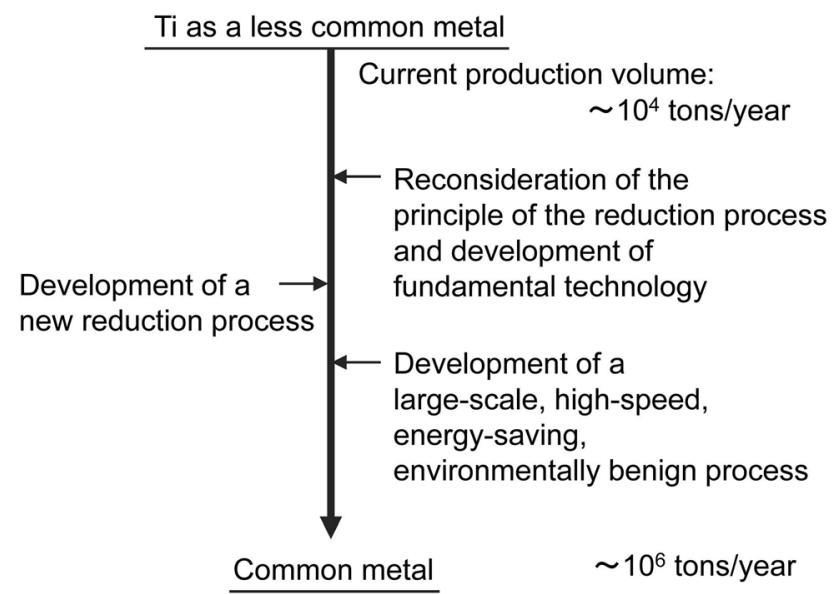

Fig. 10- Scope of development in the titanium production industry.

compared with the recycling rates for steel $(25$ pct in 2013 in Japan), aluminum (36 pct in 2016 in Japan), and copper (30 pct in 2016 in Japan). ${ }^{[66]}$ However, this nominal recycling rate does not reflect the actual material flow of titanium and its alloys.

Because titanium is an expensive metal with a price above US\$10/ $\mathrm{kg}$, recycling is well established in the smelting process for the primary metal (titanium sponge) and the machining industry for components. The real recycling rate of titanium, including cascade recycling, is estimated to be very high (above $90 \mathrm{pct}$ ) compared with that of other metals.

\section{TITANIUM SCRAPS GENERATED DURING SMELTING PROCESS}

As mentioned previously, titanium is currently produced by the Kroll process ${ }^{[17]}$ In the reduction and separation stages, iron in the steel reactor diffuses into the titanium sponge and accumulates in the titanium product as an impurity. ${ }^{[67-70]}$ In the current Kroll-based technology, the iron concentration at the bottom and side of the massive titanium sponge body is high. The titanium sponge heavily contaminated with iron cannot be used as a raw material for the production of titanium and its alloy ingots. A large amount of $\mathrm{Fe}$-contaminated titanium scrap is generated in the smelting process, which is not well-known to the public. ${ }^{[69,70]}$

The volume of off-grade titanium sponge generated in the reduction and separation processes is $10-20$ pct of the total sponge production. ${ }^{71]}$ In addition, a large amount of titanium swarf is generated in the process of machining ingots. Currently, the volume of in-house scrap is much larger than that of post-consumer titanium products.

Titanium sponge with slight iron contamination can be utilized as a raw material for the production of titanium and its alloy ingots. However, titanium sponge scrap with heavy iron contamination (generally several percent) cannot be utilized for titanium ingot production because the iron impurity in the ingot is difficult to dilute and homogenize.

The direct removal of iron impurities from titanium products is impossible by the current industrial technology. Therefore, recycling of titanium scrap containing large amounts of iron by remelting is difficult. Such titanium scrap is currently utilized as an additive (ferro-titanium: Fe-Ti alloy) for the alloying and deoxidation of steel. ${ }^{[68,69]}$ Currently, large amount of titanium scrap is consumed as ferro-titanium for steel production (cascade recycling) because the scale of steel production is significantly larger than that of titanium production.

If the titanium industry expands dramatically in the future, the supply of titanium heavily contaminated with iron could surpass the demand for ferro-titanium in the steel industry. Hence, a novel efficient technology for iron removal from titanium has to be developed, including smelting processes where the titanium sponge is free from $\mathrm{Fe}$ contamination.

\section{TITANIUM SCRAPS GENERATED IN AIRCRAFT INDUSTRY}

Approximately, $180 \mathrm{kt}$ of titanium sponge was produced by the Kroll process in 2015, and $130 \mathrm{kt}$ of it was used for producing titanium mill products. ${ }^{[3]}$ Titanium metal is primarily used for structural material in aircraft. Approximately, $80 \mathrm{kt}$ of titanium mill products was consumed by the aircraft industry in $2015,{ }^{[72]}$ and the major alloy was Ti 6-4. This alloy exhibits high specific strength and has a large capacity for impurities such as iron and oxygen. Hence, Ti 6-4 is a suitable alloy for titanium recycling by remelting.

Aluminum alloys were primarily used as structural materials in aircraft until the introduction of the Boeing 777. However, the dominant structural material for large-scale advanced aircraft is currently carbon-fiber reinforced plastic (CFRP). In the latest medium-sized jetliner, the Boeing 787, titanium alloys constitute approximately 14 mass pct of the airframe, and the energy savings are achieved by the reduction in the airframe weight. The amount of titanium alloy used as structural materials in aircraft is continuously 
increasing, ${ }^{[73]}$ because titanium alloy possesses not only a high-specific strength but also good mechanical compatibility with carbon-fiber materials owing to their similar thermal expansion coefficients. Approximately, $12 \mathrm{t}$ of titanium alloy parts is used in the Boeing 787 based on estimates. ${ }^{[74]}$

Generally, titanium alloy parts for aircrafts are produced from forged titanium ingots. To reduce the airframe weight, manufactures make the machining ratio of the titanium alloy parts very high, resulting in 80 to 90 pct of the raw material ingot eventually becoming titanium scraps such as swarf. ${ }^{[75]}$ Specifically, 90 to $120 \mathrm{t}$ of titanium alloy ingot is used for the Boeing 787 airframe, and approximately 85 pct of it becomes swarf. Hence, approximately 80 to $100 \mathrm{t}$ of titanium alloy scrap is generated in the production of a Boeing 787 airframe.

Titanium scraps such as swarf (or cutting chips, turnings) generated in the fabrication of titanium alloy parts, are collected and cleaned to remove impurities such as oil and tool fragments. The cleaned scraps are then recycled by remelting. The concentration of oxygen, the major impurity in titanium scrap, inevitably increases after remelting, and, hence, high-grade titanium ingots cannot be produced from titanium scrap only. In practical alloy production, the oxygen concentration in titanium alloys is suppressed by remelting the titanium scrap with a low-oxygen virgin titanium sponge.

\section{MATERIAL FLOW OF TITANIUM SCRAPS}

Figure 11 shows an example of the material flow of titanium..$^{[8,9,71,76]}$ The literature information regarding the material flow of titanium and its alloy scrap is few. As mentioned above, high-grade scrap is recycled to titanium ingots by remelting, whereas low-grade scrap is generally recycled to ferro-titanium (cascade recycling). However, most scraps are internationally traded, although the details on their quantity and quality are unclear.

During the recycling process of titanium and its alloys, the increase in iron concentration can be inhibited by proper scrap-separation management. However, the oxygen concentration in titanium products inevitably increases through the remelting process because the surface oxide on titanium metals dissolves into the bulk ingot during melting. Figure 12 shows approximate oxygen concentrations in titanium throughout its material flow. The present recycling volume of titanium is low, and titanium sponge with a low oxygen concentration is consistently supplied; therefore, the increment in the oxygen concentration in remelted titanium is maintained low at this stage. However, in the future, controlling the oxygen concentration in titanium scrap will be an increasingly important issue. Titanium scrap with high oxygen concentrations is subjected to cascade recycling as ferro-titanium for use as a steel additive. However, if the production scale of titanium metal is dramatically expanded in the future, the amount of generated titanium scrap may exceed the demand for

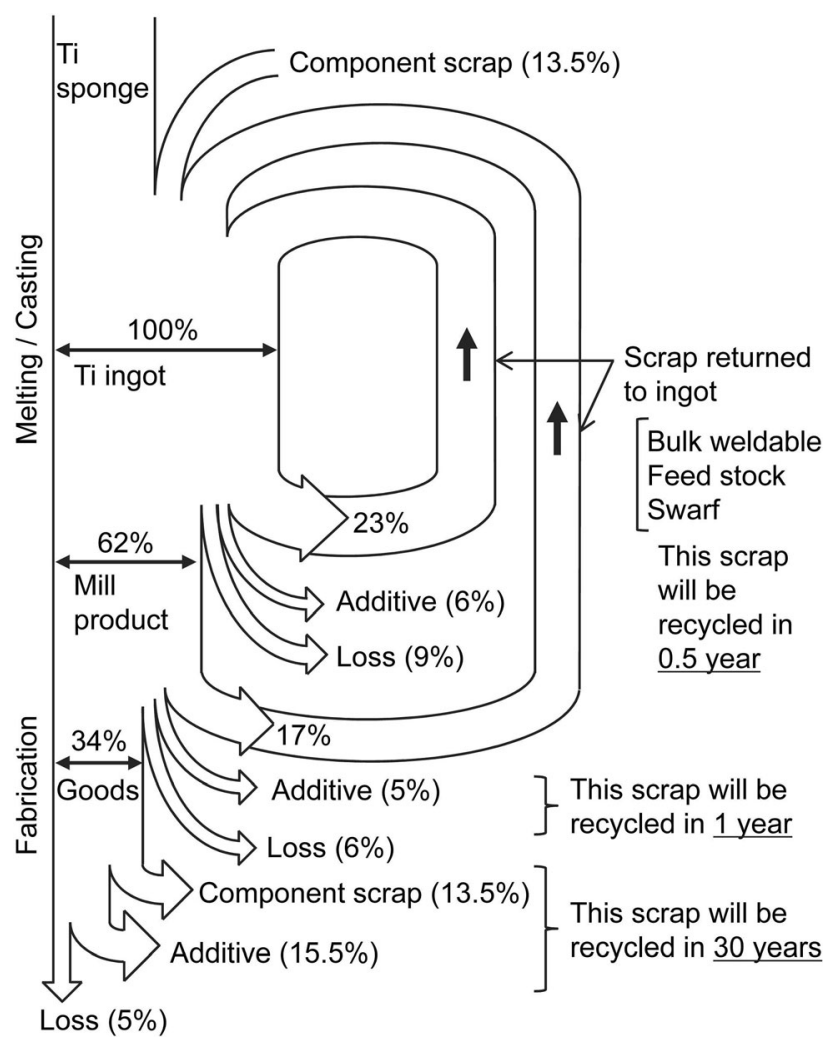

Fig. 11-Material flow of titanium scrap in Japan (2007), as estimated from literature. ${ }^{[71,76]}$ High-grade titanium scrap is remelted to produce titanium ingots (cf. Fig. 13). Low-grade titanium scrap is cascade-recycled as $\mathrm{Fe}-\mathrm{Ti}$ alloy feed material for use in steel industry.

ferro-titanium and other recycling uses. Therefore, the oxygen concentration in titanium scrap has to be decreased below several thousand mass ppm to facilitate titanium recycling.

\section{CURRENT RECYCLING PROCESS FOR TITANIUM SCRAPS}

Titanium and its alloy scraps are currently recycled by dilution with a virgin titanium sponge in the remelting process as long as the impurity concentration remain within an acceptable range. Electron-beam melting (EBM), plasma arc melting (PAM), and vacuum arc remelting (VAR) are the general remelting technologies for titanium scrap because they can minimize oxygen contamination (see Figures 13(a) to (c))..$^{[8,76]}$

EBM is appropriate for removing volatile impurity metals such as magnesium and sodium because it is operated under a high vacuum. ${ }^{[77,78]}$ However, essential components with high vapor pressures such as aluminum also evaporate, and a sophisticated technique is required for accurate control of these components. Iron cannot be removed because its vapor pressure in molten titanium is low. ${ }^{[77]}$ Furthermore, oxygen cannot be removed because its activity in molten titanium is quite low, and the oxygen concentration inevitably increases during remelting. ${ }^{[77,78]}$ In USA, the combination of 


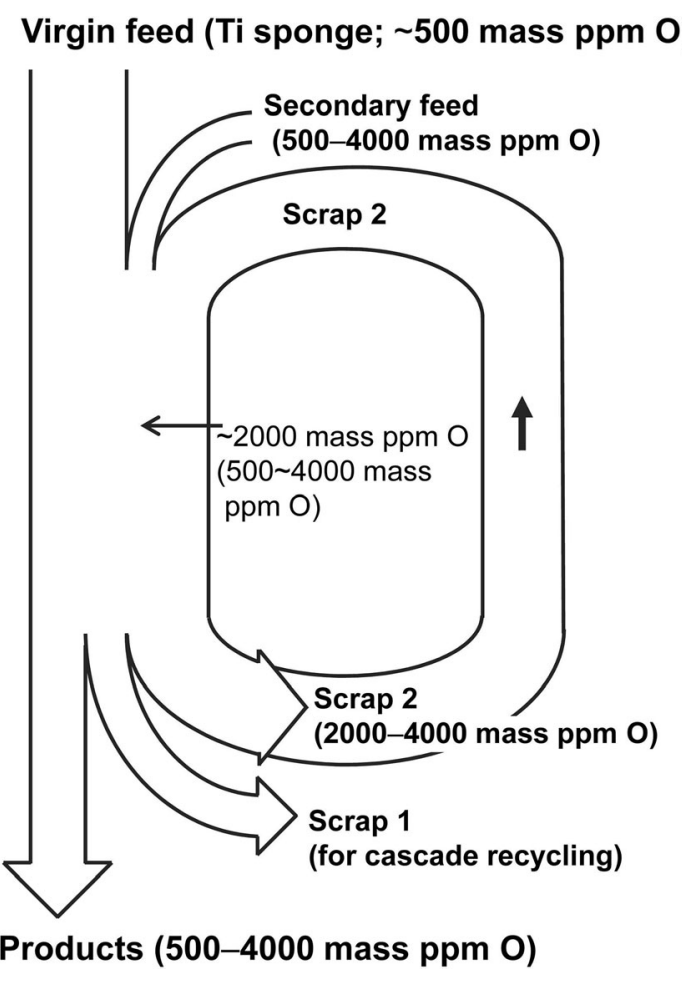

Fig. 12- Oxygen concentration during the material flow of titanium scrap measured in mass-ppm.

EBM and VAR or of PAM and VAR is generally employed for remelting. The scrap additive ratio, which depends on the price and procurement of the scrap in the market, is estimated to be 50 through 70 pct for $\mathrm{Ti}$ 6-4.

Titanium alloy scraps generated during the fabrication of parts for aircraft and other industries consists of swarf, cutting chips, and turnings. The in-house scraps are recycled by remelting. Particularly, the recycling rate of titanium alloys in the aircraft industry of USA is very high. Titanium scraps are actively sent to USA from around the world.

Titanium scrap from unknown sources and of unknown impurity levels is usually recycled as ferro-titanium in the steel industry. Low-grade scrap with high impurity levels is also recycled as ferro-titanium. A low-cost remelting method, such as induction melting (IM), is generally applied in this case as contamination with iron and oxygen from the crucibles and other equipment is not a major issue. ${ }^{[8,76]}$

\section{CURRENT STATUS OF RESEARCH AND DEVELOPMENT IN TITANIUM SCRAP RECYCLING}

The method of oxygen removal from titanium metal is one of the most important recycling technologies. With the presently available technology, the direct removal of oxygen from titanium metal is very difficult. Therefore, most studies on oxygen removal are at an early stage

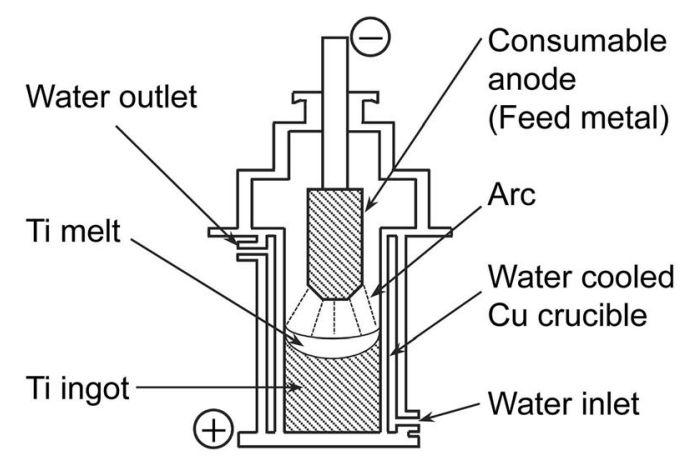

(a) Vacuum arc remelting (VAR)

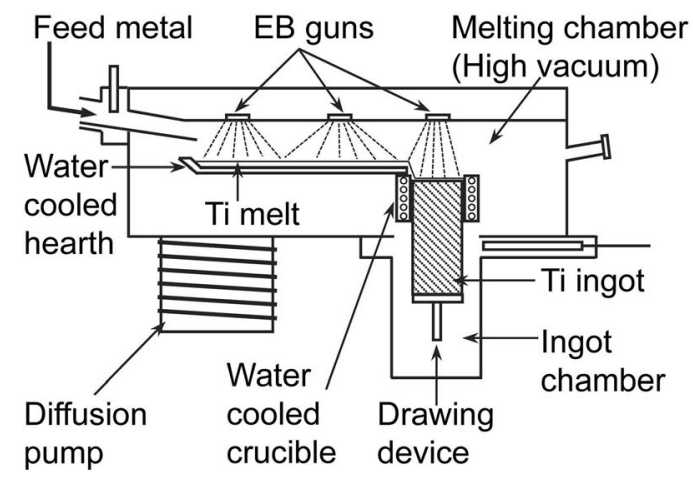

(b) Electron beam melting (EBM)

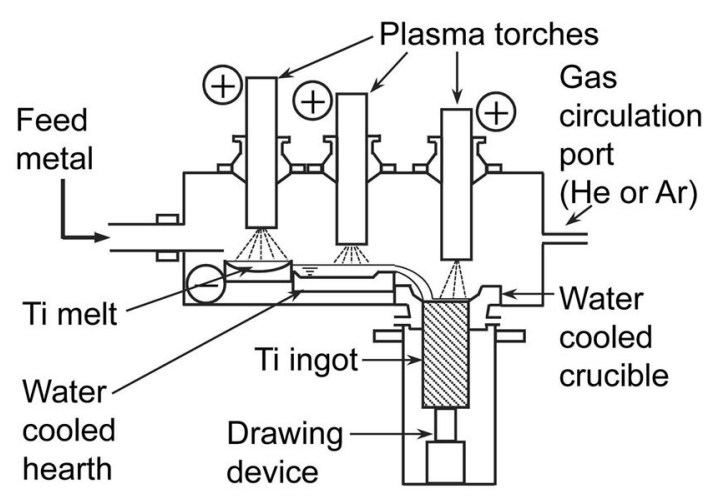

(c) Plasma arc melting (PAM)

Fig. 13-Schematic illustration of various remelting processes for producing titanium and titanium alloys under an inert atmosphere. ${ }^{[8,76]}$

except for a few industrial processes, namely, the deoxidation of titanium scrap by calcium metal ${ }^{[79-82]}$ and the electrorefining of titanium sponge in molten salts. ${ }^{[83]}$

Electrorefining of titanium metal in molten salts has been investigated for years. ${ }^{[49,50,83-85]}$ In this process, crude titanium metal is anodically dissolved into molten salt as titanium ions on the anode, and high-purity titanium is deposited on the cathode, as shown in the following electrode reactions: 


$$
\text { Anode }: \operatorname{Ti}(s)=\operatorname{Ti}^{n+}(\text { in molten salt })+n e^{-}
$$

$$
\text { Cathode }: \mathrm{Ti}^{n+} \text { (in molten salt) }+n e^{-}=\operatorname{Ti}(s)
$$

Not only oxygen but also many impurities can be removed by the electrolysis. However, the titanium product is inevitably contaminated with alkali metals $(\mathrm{Na}$ and $\mathrm{K}$ ) and chlorine $(\mathrm{Cl})$, and morphology control of the titanium deposits is difficult. An additional refining process such as EBM is sometimes employed after the electrorefining process to remove the impurities.

As mentioned previously, Ono and Miyazaki conducted pioneering research on calcium deoxidation, ${ }^{[31]}$ and Fischer and Seagle subsequently developed it into an industrial process, ${ }^{[39-82]}$ where the oxygen in titanium is removed as $\mathrm{CaO}$. These studies led to the development of the Ca-halide flux deoxidation ${ }^{[32-35]}$ and the electrochemical deoxidation ${ }^{[36]}$ processes by Okabe et al. Subsequently, Chen et al. developed the FFC process, ${ }^{[29]}$ which inspired many similar studies.

Yahata et al. studied the deoxidation method that employs aluminum metal as the deoxidizing agent by using EBM. ${ }^{[86]}$ EBM provides a high temperature and high vacuum condition, which enables the removal of oxygen as aluminum suboxide vapor.

$$
\underline{\mathrm{O}}(\text { in } \mathrm{Ti}(l))+\mathrm{Al}(l)=\mathrm{AlO}(g)
$$

Deoxidation of titanium metal in molten state is difficult because of its high reactivity. Nevertheless, the development of deoxidation processes for molten titanium is anticipated because the productivity and industrial viability are high.

Matsuoka et al. developed a recycling process that utilizes chlorination of titanium metal with iron chlorides. This process is effective for heavily contaminated titanium scrap. ${ }^{[87]}$

$$
\mathrm{Ti}(s)+4 \mathrm{FeCl}_{3}(g)=\mathrm{TiCl}_{4}(g)+4 \mathrm{FeCl}_{2}(s)
$$

Titanium is extracted as $\mathrm{TiCl}_{4}$, which is then returned to the Kroll process. The iron chloride generated during the chlorination process in the Kroll process can be used as a chlorination agent. This recycling process is expected to become a key technology that can be applied to titanium scrap heavily contaminated with iron.

Taninouchi et al. developed an efficient chlorination process that uses a reaction-mediating molten salt. ${ }^{[8]}$

$$
\begin{aligned}
& \mathrm{Ti}(s)+4 \underline{\mathrm{SmCl}_{3}}(l, \text { in molten salt }) \\
& =\mathrm{TiCl}_{4}(g)+4 \underline{\mathrm{SmCl}_{2}}(l, \text { in molten salt }) \\
& \quad \frac{2 \mathrm{SmCl}_{2}(l, \text { in molten salt })+\mathrm{FeCl}_{2}(s)}{=2 \underline{\mathrm{SmCl}_{3}}(l, \text { in molten salt })+\mathrm{Fe}(s)}
\end{aligned}
$$

Titanium metal is efficiently chlorinated in this process because both the chlorination agent and the reaction product are dissolved species in molten salts. This process can be applied not only to pure titanium but also to titanium alloys. Further development of this process is anticipated to lead to its industrialization.

On the basis of thermodynamic estimations, Okabe et al. proposed that titanium with an ultra-low oxygen concentration can be produced using rare-earth halides as fluxes by forming rare-earth oxyhalides (REOX; $\mathrm{X}=$ $\mathrm{F}$ or $\mathrm{Cl}) \cdot{ }^{[89,90]}$ For example, when titanium is deoxidized using yttrium (Y) as the deoxidizing agent in an yttrium chloride $\left(\mathrm{YCl}_{3}\right)$ flux, a $\mathrm{Y} / \mathrm{YOCl} / \mathrm{YCl}{ }_{3}$ equilibrium is established in the system. In this system, titanium is deoxidized by yttrium along with $\mathrm{YOCl}$ formation according to the following reaction:

$$
\underline{\mathrm{O}}(\text { in } \mathrm{Ti}(s))+2 / 3 \mathrm{Y}(s)+1 / 3 \mathrm{YCl}_{3}(l)=\mathrm{YOCl}(s)
$$

The calculated oxygen concentration in titanium at equilibrium and at $1027{ }^{\circ} \mathrm{C}(1300 \mathrm{~K})$ is lower than 10 mass-ppm O.$^{[89]}$ Thermodynamically, only a few metals, such as calcium and rare-earth metals, have sufficient ability to deoxidize titanium. If the deoxidation of titanium is feasible using magnesium as the deoxidizing agent in a $\mathrm{MgCl}_{2}$ flux, the reduction and electrolysis facilities used in the conventional Kroll process could be utilized, which would be advantageous for practical applications. However, it is impossible to reduce the oxygen concentration of $\mathrm{Ti},[\mathrm{O}]_{\mathrm{Ti}}$, to levels below 1 mass pct $(10,000 \mathrm{ppm}) \mathrm{O}$ simply by using magnesium and $\mathrm{MgCl}_{2}$ owing to the low deoxidation ability of magnesium through the formation of $\mathrm{MgO}[\underline{\mathrm{O}}($ in $\mathrm{Ti}(s))+\mathrm{Mg}(l) \rightarrow \mathrm{MgO}(s)]$, making it incompatible for industrial application.

To obtain titanium with a low oxygen concentration using magnesium as the deoxidizing agent in a $\mathrm{MgCl}_{2}$ flux, the activity of $\mathrm{MgO}, a_{\mathrm{MgO}}$, in the system must be reduced and maintained at a low level during deoxidation. For example, to obtain titanium with 500 mass ppm $\mathrm{O}, a_{\mathrm{MgO}}$ must be decreased to 0.02 at $1300 \mathrm{~K}$.

To decrease $a_{\mathrm{MgO}}$ to low levels, Okabe et al. developed a new process by adding $\mathrm{RECl}_{3}$ to the $\mathrm{MgCl}_{2}$ flux. ${ }^{\left[{ }^{89-92]}\right.}$ In the mixture of $\mathrm{MgCl}_{2}-\mathrm{RECl}_{3}$, magnesium metal is stable and functions as the deoxidizing agent. Subsequently, the oxygen in titanium reacts with magnesium and $\mathrm{RECl}_{3}$ to form $\mathrm{REOCl}$ by the following reaction:

$$
\begin{aligned}
& \underline{\mathrm{O}} \text { (in } \mathrm{Ti})+\mathrm{Mg}(l)+\underline{\mathrm{RECl}_{3}} \text { (in molten salt) } \\
& \left.\quad \rightarrow \underline{\mathrm{MgCl}_{2}} \text { (in molten salt }\right)+\operatorname{REOCl}(s)
\end{aligned}
$$

Through this reaction, the process reduces the oxygen concentration in titanium to levels significantly lower than those obtained using the magnesium deoxidizing agent in $\mathrm{MgCl}_{2} \cdot{ }^{[91,92]}$

To further decrease the oxygen concentration in titanium directly from titanium scrap, more recent studies developed an electrochemical deoxidation method using magnesium as the deoxidizing agent in a mixture of $\mathrm{MgCl}_{2}$ and $\mathrm{RECl}_{3}$ (RE: Y and Ho) (Figure 14). ${ }^{[93,94]}$ The oxygen concentration in titanium was thereby decreased to less than $500 \mathrm{ppm}$. 


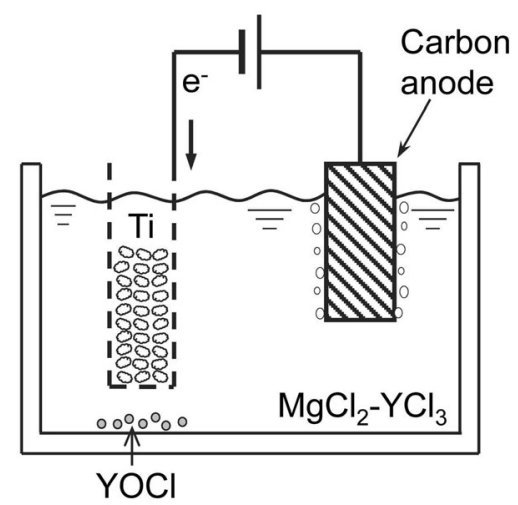

$[O]_{\text {in Ti }}+\mathrm{Mg}(l)+\mathrm{YCl}_{3}(l)=\mathrm{MgCl}_{2}(l)+\mathrm{YOCl}(s)$

Fig. 14-Schematic illustration of the reaction system in the electrochemical deoxidation process in molten $\mathrm{MgCl}_{2}-\mathrm{YCl}_{3}$ assisted by YOCl formation. ${ }^{[91-94]}$

The development of low-cost technologies to remove iron and oxygen impurities will allow an increase in the scrap usage for remelting during ingot production. Therefore, these technologies are crucial for improving the recycling rate of titanium scrap.

\section{CONCLUSIONS}

The first industrial production process of titanium metal achieved after the discovery of the titanium element was the magnesiothermic reduction of $\mathrm{TiCl}_{4}$, i.e., the Kroll process. From 1950s to 1970s, electrolytic smelting methods were actively investigated to replace the Kroll process with more efficient methods. However, the industrialization of electrolytic methods did not succeed. Subsequently, processes employing both electrolytic and metallothermic reduction were widely studied. The development of reduction processes of titanium oxide using calcium metal as a reductant has advanced significantly. However, numerous problems remain to be resolved before realizing the practical application of the smelting process utilizing oxide feed. To make titanium a "common metal", the new reduction process that is high speed, energy efficient, low cost, and of a low environmental impact. A breakthrough in elemental technologies is expected.

The major resource in titanium recycling is in-house scraps generated during smelting and fabrication processes, and the actual recycling rate of titanium, including the in-house cascade recycling rate, is high. The major and problematic impurities contained in the titanium scrap are oxygen and iron. High-grade titanium scraps with low oxygen and iron concentrations are recycled to titanium and its alloy ingots by remelting. Low-grade titanium scraps with high oxygen and iron concentrations are utilized as the raw material of ferro-titanium for the steel industry. However, if the demand for titanium metal increases dramatically in the future, the supply of low-grade titanium scrap will surpass the demand for ferro-titanium.
Anti-contamination and removal technologies for oxygen and iron have to be developed for the efficient utilization of titanium.

The production cost of titanium must be decreased to significantly expand the titanium market. The amount of titanium used in the automobile industry is limited owing to its high production cost. If the production cost is drastically decreased, the demand for titanium would increase dramatically. The amount of scrap generation would increase accordingly, and thus, the technologies to efficiently remove impurities such as iron and oxygen from titanium scraps will be more important. Therefore, it is essential for the expansion of the titanium industry to bring innovation to both titanium smelting and recycling technologies.

\section{ACKNOWLEDGMENTS}

The authors are grateful to Professor Emeritus William G. Davenport of University of Arizona, and to Mr. Osamu Koike, and Mr. Kazuhiro Kinoshita of the Japan Titanium Society, to Mr. Kazuhiro Taki of Toho Technical Service Co. Ltd., to Mr. Yuichi Ono of Toho Titanium Co. Ltd., and to Associate Professor Yuki Taninouchi of Kyoto University for their valuable comments and suggestions. This research was partly funded by a Grant-in-Aid for Scientific Research (S) (KAKENHI Grant \#26220910 and 19H05623) by JSPS.

\section{CONFLICT OF INTEREST}

On behalf of all authors, the corresponding author states that there are no conflicts of interest associated with this study.

\section{REFERENCES}

1. R.L. Rundnick: The Crust, Elsevier Pergamon, Oxford, UK, 2004, pp. 1-64.

2. F.H. Froes: Titanium; Physical Metallurgy Processing and Applications, ASM International, Materials Park, OH, 2015, pp. 9-14, 331.

3. Industrial Rare Metal, Annual Review 2017, Arumu Publishing, Tokyo, Japan, 2017, pp. 70-75, 86. (in Japanese).

4. O. Takeda, T. Uda, and T.H. Okabe: Treatise on Process Metallurgy, Vol. 3, Elsevier, London, Chap. 2.9, 2013, pp. 995-1069.

5. T.H. Okabe and O. Takeda: Extractive Metallurgy of Titanium, Chapter 5, ed. Z.Z. Fang, F.H. Froes, Y. Zhang, Elsevier, 2019, pp. 65-95.

6. T.H. Okabe: Extractive Metallurgy of Titanium, Chapter 8, ed. Z.Z. Fang, F.H. Froes, Y. Zhang, Elsevier, 2019, pp. 131-64.

7. Y. Zhang, Z.Z. Fang, P. Sun, S. Zheng, Y. Xia, and M. Free: JOM, 2017, vol. 69, pp. 1861-68.

8. O. Takeda and T.H. Okabe: JOM, 2018, vol. 70, pp. 1981-90.

9. O. Takeda and T.H. Okabe: Extractive Metallurgy of Titanium, Chapter 16, ed. Z.Z. Fang, F.H. Froes, Y. Zhang, Elsevier, 2019, pp. 363-87.

10. Y. Xia, J. Zhao, Q. Tian, and X. Guo: JOM, 2019, vol. 71, pp. 3209-3220.

11. J. Moriyama: J. Suiyoukai, 1995, vol. 22, pp. 185-92 (in Japanese). 
12. L.F. Nilson and O. Petterson: Z. Physc. Chem. 1887, Bd., 1, pp. $27-38$.

13. M.A. Hunter: J. Am. Chem. Soc., 1910, vol. 32, pp. 330-36.

14. O. Ruff and H. Brintzinger: Z. Anorg. Allgem. Chem., 1923, vol. 129 , pp. $267-75$.

15. W. Kroll: Z. Anorg. Allgem. Chem., 1937, vol. 234, pp. 42-50 (in German).

16. A.E. van Arkel and J.H. de Boer: Z. Anorg. Allg. Chem., 1925, vol. 148 , pp. $345-50$.

17. W. Kroll: Trans. Electrochem. Soc., 1940, vol. 78, pp. 35-47.

18. W.J. Kroll: A Luxembourg scientist, Foundation Nicolas Lanners, Luxembourg, 1998.

19. H. Kusamichi and J. Iseki: Titanium Industry and the New Technology in Japan, Agune Gijyutsu Center, Tokyo, Japan, 1996, pp. 45-55. (in Japanese).

20. T. Hyodo and N. Mochizuki: J. MMIJ, 2007, vol. 123, pp. 698 703 (in Japanese).

21. S. Kosemura, S. Anbo, E. Fukasawa, and Y. Hatta: J. MMIJ, 2007, vol. 123, pp. 693-97 (in Japanese).

22. W. Borchers and W. Hupperts: Brit. Pat. Spec. 13759, June 17 , 1904; German Patent 150, 557, 1903.

23. M.E. Sibert and M.A. Steinberg: J. Metals, 1956, Sept., 1162-68.

24. W.R. Opie and O.W. Moles: Trans. AIME, 1960, vol. 218, pp. 646-49.

25. M.J. Rand and L.J. Reimert: J. Electrochem. Soc., 1964, vol. 111, pp. 429-33.

26. O.Q. Leone, H. Knudsen, and D. Couch: J. Metals (JOM), 1967 , vol. 19 , pp. $18-23$.

27. C.-J. Hsueh, M. Antloga, C. Virnelson, U. Landau, M. DeGuire, and R. Akolkar, ECS 2015 Meeting Abstracts, 2015, vol. MA2015-01, p. 1224.

28. T. Oki and H. Inoue: Mem. Fac. Eng., Nagoya Univ., 1967, vol. 19, pp. 164-66.

29. G.Z. Chen, D.J. Fray, and T.W. Farthing: Nature, 2000, vol. 407, pp. 361-64.

30. K. Ono and R.O. Suzuki: JOM, 2002, vol. 54, pp. 59-61.

31. K. Ono and S. Miyazaki: J. Jpn. Inst. Met., 1985, vol. 49, pp. 87175 (in Japanese).

32. T.H. Okabe, R.O. Suzuki, T. Oishi, and K. Ono: Mater. Trans. JIM, 1991, vol. 32, pp. 485-88.

33. T.H. Okabe, R.O. Suzuki, T. Oishi, and K. Ono: Tetsu-to-Hagane, 1991, vol. 77, pp. 93-99 (in Japanese).

34. T.H. Okabe, T. Oishi, and K. Ono: J. Alloys Compd., 1992, vol. 184 , pp. $43-56$

35. T.H. Okabe, T. Oishi, and K. Ono: Metall. Trans. B, 1992, vol. 23B, pp. 583-90.

36. T.H. Okabe, M. Nakamura, T. Oishi, and K. Ono: Metall. Trans. $B, 1993$, vol. 24B, pp. 449-55.

37. G.Z. Chen, D.J. Fray, and T.W. Farthing: Metall. Trans. B, 2001, vol. $32 \mathrm{~B}$, pp. 1041-52.

38. G.Z. Chen, D.J. Fray, and T.W. Farthing: 2004, US Patent No. 2004/0159559 A1.

39. I. Barin: Thermochemical Data of Pure Substances, 3rd ed., VCH Verlagsgesellschaft, 1997.

40. M. Yamaguchi, T. Ogasawara, and H. Ichihashi: Proc. 11th World Conference on Titanium, Ti 2007, 2007, pp. 147-150.

41. G. Crowley: Adv. Mater. Proc., 2003, vol. 161, pp. 25-27.

42. I. Mellor, G. Doughty, M. Piper, T. Ellis, K. Rao, and J. Dean: Proc. 13th World Conf. Titanium, 2016, pp. 145-50.

43. N.R. Neelameggham, B.R. Davis, and M.A. Imam: Proc. 13th World Conf. Titanium, 2016, pp. 87-91.

44. T.H. Okabe, T. Oda, and Y. Mitsuda: J. Alloys Compd., 2004, vol. 364, pp. 156-63.

45. T.H. Okabe, S. Iwata, M. Imagunbai, Y. Mitsuda, and M. Maeda: ISIJ Int., 2004, vol. 44, pp. 285-93.

46. T.H. Okabe, S. Iwata, M. Imagunbai, and M. Maeda: ISIJ Int., 2003, vol. 43, pp. 1882-89.

47. T.H. Okabe, N. Sato, Y. Mitsuda, and S. Ono: Mater. Trans., JIM, 2003, vol. 44 2646-53.

48. E. Wainer: US Patent, 1952, No. 2868703

49. S. Takeuchi and O. Watanabe: J. Jpn. Inst. Metals, 1964, vol. 28 , pp. $627-32$.

50. T. Hashimoto: J. Jpn. Inst. Metals, 1968, vol. 32, pp. 1327-33.

51. S. Jiao and H. Zhu: J. Mater. Res., 2006, vol. 21, pp. 2172-75.
52. J.C. Withers, R.O. Loutfy, and J.P. Laughlin: Mater. Technol., 2007, vol. 22, pp. 66-70.

53. D. Fray: ECS Trans., 2012, vol. 50, pp. 3-13.

54. A.C. Halomet: British Patent, 1970, No. 1187367.

55. M.V. Ginatta, Proceedings of EPD Congress 2001, TMS (New Orleans, Feb. 11-15, 2001) ed. P.R. Taylor, 2001, pp. 13-41.

56. M.V. Ginatta: Light Metal Age, 2004, vol. 62, pp. 48-51.

57. M.V. Ginatta, Proceedings of International Round Table on Titanium Production in Molten Salts, Cologne, Germany, March 2-4, 2008.

58. R.A. Hard, and M.A. Prieto: US Patent, 1983, No. 4390365.

59. E. Kimura, M. Ogi, and K. Sato: Japan Patent, 1985, No. S-60-89529.

60. T. Deura, T.H. Okabe, T. Oishi, and K. Ono: Abstracts of 24th Symposium on Molten Salt Chemistry, Japan (Nov. 11-12, 1992, Kyoto, Japan), Molten Salt Committee, the Electrochemical Society of Japan.

61. Y. Kado, A. Kishimoto, and T. Uda: Metall. Mater. Trans. B, 2015, vol. 46B, pp. 57-61.

62. Z.Z. Fang, S. Middlemas, J. Guo, and P. Fan: J. Am. Chem. Soc., 2013, vol. 135 , pp. $18248-51$.

63. O. Takeda and T.H. Okabe: Mater. Trans., 2006, vol. 47, pp. $1145-54$

64. O. Takeda and T.H. Okabe: Metall. Mater. Trans. B, 2006, vol. $37 \mathrm{~B}$, pp. $823-30$.

65. O. Takeda and T.H. Okabe: J. Alloys Compd., 2008, vol. 457, pp. $376-83$.

66. Mineral resource material flow 2017, 2017. Japan Oil, Gas, Metals National Corporation, Tokyo, Japan. http://mric.jogmec.go.jp/wp-c ontent/ebook/201803/5ab321a5/material_flow2017.pdf. Accessed Apr 1, 2018 (in Japanese).

67. Home page of Toho Titanium Co., Ltd., 2018. (http://www.tohotitanium.co.jp) Accessed Apr 1, 2018.

68. Y. Marui, T. Kinoshita, and K. Takahashi: Honda R\&D Tech. Rev., 2002, vol. 14, pp. 149-56 (in Japanese).

69. T. Suzuki and T. Kaneko: The Latest Technological Trend of Rare Metals, CMC Publishing, Tokyo, Japan, 2012, Chap. 6.4, pp. 117-27. (in Japanese).

70. Y. Taninouchi, Y. Hamanaka, and T.H. Okabe: Mater. Trans., 2015, vol. 56, pp. 1-9.

71. Y. Taninouchi, Y. Hamanaka, and T.H. Okabe: Proceedings of Ti-2015: The 13th World Conference on Titanium (August 16-20, 2015, San Diego, USA, 2015), The Minerals, Metals \& Materials Society, Pittsburgh, PA, USA, 2015, pp. 165-70.

72. E. Roegner: Proceedings of Titanium USA 2016 (Sep. 25-28, 2016, Scottsdale, AZ, USA), International Titanium Association, Northglenn, CO, USA, 2016.

73. W. Leach: Proceedings of Titanium 2015 (Oct. 4-7, 2015, Orlando, FL, USA), International Titanium Association, Northglenn, CO, USA, 2015.

74. H. Hira: J. Jpn. Inst. Light Metals, 2015, vol. 65, pp. 426-31 (in Japanese).

75. R. Duflos: Proceedings of Titanium USA 2016 (Sep. 25-28, 2016, Scottsdale, AZ, USA), International Titanium Association, Northglenn, CO, USA, 2016.

76. T. Suzuki: Titanium Jpn., 2009, vol. 57, pp. 21-29 (in Japanese).

77. T. Ishigami: Materia Jpn., 1994, vol. 33, pp. 55-57 (in Japanese).

78. X. Lu, T. Hiraki, K. Nakajima, O. Takeda, K. Matsuabe, H. Zhu, S. Nakamura, and T. Nagasaka: Sep. Purif. Technol., 2012, vol. 89 , pp. 135-41.

79. R.L. Fisher: US Patent, 1990, No. 4923531A.

80. R.L. Fisher: US Patent, 1991, No. 5022935.

81. R.L. Fisher and S. R. Seagle: US Patent, 1993, No. 5211775 A.

82. R.L. Fisher and S. R. Seagle: Proceedings of the 7th World Conference on Titanium (1992)), vol. 3, F.H. Froes and I. Caplan, eds., The Minerals, Metals \& Materials Society, Pittsburgh, PA, USA, 1993, pp. 2265-72.

83. H. Miyazaki, Y. Yamakoshi, and Y. Shindo: Materia Jpn., 1994, vol. 33, pp. 51-54 (in Japanese).

84. J.R. Nettle, D.H. Baxer, Jr, and F.S. Wartman: United States Bureau of Mines, Report of Investigations 5315, USBM, Washington, DC, 1957.

85. A.B. Suchkov, Z.A. Tubyshki, Z.I. Sokolova, and N.V. Zhukova: Russ. Metall., 1969, vol. 6, pp. 52-53. 
86. T. Yahata, T. Ikeda, and M. Maeda: Metall. Trans. B, 1993, vol. 24B, pp. 599-604.

87. R. Matsuoka and T.H. Okabe: Proceedings of the Symposium on Metallurgical Technology for Waste Minimization at the 2005 TMS Annual Meeting (San Francisco, CA, 2005.2.13-17), The Minerals, Metals \& Materials Society, Pittsburgh, PA, 2005.

88. Y. Taninouchi, Y. Hamanaka, and T.H. Okabe: Mater. Trans., 2016, vol. 57, pp. 1309-18.

89. T.H. Okabe, C. Zheng, and Y. Taninouchi: Metall. Mater. Trans. B, 2018, vol. 49B, pp. 1056-66.

90. T.H. Okabe, Y. Taninouchi, and C. Zheng: Metall. Mater. Trans. $B, 2018$, vol. 49 B, pp. $3107-17$.
91. C. Zheng, T. Ouchi, A. Iizuka, Y. Taninouchi, and T.H. Okabe: Metall. Mater. Trans. B., 2019, vol. 50B, pp. 622-31.

92. L. Kong, T. Ouchi, and T.H. Okabe: Mater. Trans., 2019, vol. 60, pp. 2059-68.

93. L. Kong, T. Ouchi, and T.H. Okabe: J. Electrochem. Soc., 2019, vol. 166, pp. E429-37.

94. C. Zheng, T. Ouchi, L. Kong, Y. Taninouchi, and T.H. Okabe: Metall. Mater. Trans. B, 2019, vol. 50B, pp. 1652-61.

Publisher's Note Springer Nature remains neutral with regard to jurisdictional claims in published maps and institutional affiliations. 